Food Is Love 



\section{Food Is Love}

Food Advertising and Gender Roles in Modern America

KATHERINE J. PARKIN

$\overline{\text { PENN }}$

University of Pennsylvania Press

Philadelphia 
Copyright @ 2006 University of Pennsylvania Press

All rights reserved

Printed in the United States of America on acid-free paper

$\begin{array}{llllllllll}10 & 9 & 8 & 7 & 6 & 5 & 4 & 3 & 2 & 1\end{array}$

Published by

University of Pennsylvania Press

Philadelphia, Pennsylvania 19104-4122

Library of Congress Cataloging-in-Publication Data

Parkin, Katherine J.

Food is love : food advertising and gender roles in modern America / Katherine J. Parkin.

p. $\mathrm{cm}$.

ISBN-13: 978-0-8122-3929-4 (alk. paper)

ISBN-10: 0-8122-3929-6

Includes bibliographical references and index.

1. Sex role in advertising-United States-History. 2. Advertising-Food-United States-History. 3. Women consumers-United States-History. 4. Women in advertising-United States-History. 5. Men in advertising-United States-History. I. Title.

HF5827.85.P37 2006

$659.19^{\prime} 66400973-\mathrm{dc} 22$

2006042227 
For Chris 
